\title{
Comparison of Botryococcus braunii and Neochloris vigensis Biofillm Formation on Vertical Oriented Surfaces
}

\author{
Vasiliki D. Tsavatopoulou ${ }^{1}$, Andriana F. Aravantinou ${ }^{1}$, Ioannis D. Manariotis ${ }^{1}$ * (DD \\ 1 Environmental Engineering Laboratory, Department of Civil Engineering, University of Patras, 26504 Patras, Greece; \\ vasoutsav@gmail.com (V.D.V.); andriana.aravntinou@gmail.com (A.F.A.); idman@upatras.gr (I.D.M.); \\ * Correspondence: idman@upatras.gr;
}

Scopus Author ID 6506601790

Received: 21.12.2020; Revised: 18.01.2021; Accepted: 22.01.2021; Published: 31.01.2021

\begin{abstract}
Biofilm technology is a cost-effective process for microalgae biomass production. Materials can be successfully used as microalgae biomass adhesion carriers. The productivity of two different microalgal strains, Neochloris vigensis, and Botryococcus braunii, were compared in an opened pond system on eleven different surfaces (cork, sponge towel, denim, plexiglass, stainless steel, silicone rubber, glass, geotextile, and three different patterned plexiglass). Biomass attachment on the various materials was monitored for 16 days of cultivation. Various parameters were tested during cultivation, such as $\mathrm{pH}$, cell concentration, chl-a, $\mathrm{NO}_{3}{ }^{-}, \mathrm{PO}_{4}{ }^{3-}$, lipids, total proteins, and carbohydrates. Contact angle and surface energy were used to determine the surface characteristics. Plexiglass resulted in the best performance in the case of B.braunii $\left(28.3 \mathrm{~g} / \mathrm{m}^{2}\right)$, while in the case of $N$.vigensis, sponge towel exhibited the highest productivity $\left(17.8 \mathrm{~g} / \mathrm{m}^{2}\right)$. Based on the results, the algal strain affects the attachment, and hydrophilic materials can be as efficient as hydrophobic ones.
\end{abstract}

Keywords: microalgae; biofilm; vertical surfaces; coupons.

(C) 2021 by the authors. This article is an open-access article distributed under the terms and conditions of the Creative Commons Attribution (CC BY) license (https://creativecommons.org/licenses/by/4.0/).

\section{Introduction}

In the last decades, many studies have been focused on microalgae cultivation since their biochemical composition constitutes a promising green product with numerous uses $[1$, 2]. Amino acids, pigments, carbohydrates, polysaccharides, vitamins, and antioxidants can be used in pharmaceuticals and cosmetics, such as food additives, aquaculture feed, and bioplastics [3]. The high lipid content of algal biomass gives them the advantage of a sustainable source for biodiesel production. Algae biomass can be produced at higher rates than the common oilseed crops [4]. However, the production of biofuels and bioproducts from algal biomass is still in the infant stage due to the lack of any reliable and cost-effective harvesting method [5]. A major challenge for implementing an integrated algal system includes the harvesting and processing of biomass to allow downstream processing for the production of biofuels and other valuable bioproducts [5]. Algal biomass harvesting is estimated to be around 30 to $40 \%$ of algal cultivation's total operating cost [6]. Recently, algal biofilm systems have drawn interest as an alternative to suspended culture systems [7]. Algal biofilm can be collected simply by scraping. The solid content of algal biomass is 10 to $20 \%$, which is higher than that obtained from suspended cultures by centrifugation $[8,9]$.

More specifically, in attached systems, the algal biomass is directly inoculated onto the surfaces, and biofilm is formed by providing the required nutrients (synthetic medium or wastewater) [10-12]. Biofilms are complex communities of microorganisms, including 
bacteria, fungi, cyanobacteria, and algae [13]. The application of attached algal cultivation systems also benefits the remediation of wastewater. It can assimilate the available nutrients, such as nitrogen and phosphorus [14-16]. The presence of bacteria aids the whole process of attachment, especially in the early stages of cultivation [6].

Biofilm production and biomass attachment are affected by many abiotic and biotic factors [13]. The supporting material and its physicochemical characteristics are the main factors for microalgae adhesion and biofilm creation. Various materials with different textures and properties have been considered supporting carriers, such as metals, natural and synthetic polymers $[6,11,17,18]$. The physicochemical properties such as surface tension, surface wettability, water contact angle, and hydrophobicity seem to be crucial factors in promoting algal cells' attachment. The mechanism of adhesion has been studied by many researchers who reported that hydrophobic materials were most favorable for algal attachment [19-21]. Generally, most of the microalgal species are hydrophobic. Hence, the cells prefer to adhere to hydrophobic supporting materials to minimize their contact with water [22]. From the moment the cells start to adhere, they secrete natural polymers such as proteins and carbohydrates, which favor cell adhesion on the supporting material [23]. However, recent research suggests that not only hydrophobic materials perform well, so that contact angle alone is not sufficient as a criterion for selecting a material [10, 24, 25].

Apart from supporting material, the algal strain also plays a crucial role in the attachment process [26]. Irving and Allen [10] examined Scenedesmus obliquus and Chlorella vulgaris and found out that the latter exhibited higher initial attachment in axenic conditions. Moreover, recent studies [27] reported that even the same species cultured in different nutrient concentrations might exhibit different biofilm production. Many microalgae species (Scenedesmus obliquus, Chlorella vulgaris, Botryococcus braunii, Nannochloropsis oculata, etc.) have been investigated for biofilm production $[10,17,28]$.

This study aimed to investigate the biofilm growth of two high lipid microalgae species Neochloris vigensis and Botryococcus braunii, on eleven different supporting materials in an open pond configuration system. The manuscript focuses on algae species' effect and the supporting material with different physicochemical characteristics on biofilm production. Moreover, the microalgae characteristics such as protein, carbohydrates, and lipid content in the suspended culture of $N$. vigensis and B. braunii were analyzed to investigate the differences between the algal species.

\section{Materials and Methods}

\subsection{Microalgae strains and culture.}

Botryococcus braunii (SAG 807-1), Neochloris vigensis (80.80) were obtained from the Sammlung von Algenkulturen der Universität Göttingen (Culture Collection Algae at Göttingen University) bank (SAG). Algal precultures were prepared with modified 1/3N BG11 medium (Blue Green-11 enriched with one-third times the nitrates concentration) in 1-L Erlenmeyer flasks. The flasks were illuminated by fluorescent lights $\left(22 \mu \mathrm{mol} / \mathrm{m}^{2} \mathrm{~s}\right)$ with constant aeration $(3.5 \mathrm{~L} / \mathrm{min})$. They were placed in a walk-in incubator room under controlled environmental conditions at $20^{\circ} \mathrm{C}$. The specific growth rate $(\mu)$ was determined from the growth phase by the following equation [29]:

$$
\mu=\frac{\ln X_{t}-\ln X_{0}}{t-t_{0}}
$$


Where, $\mathrm{X}_{\mathrm{t}}$ is the number of cells at time $\mathrm{t}$ (days), and $\mathrm{X}_{0}$ the initial number of cells at time $\mathrm{t}_{0}$. The algal biofilm productivity $\left(\mathrm{g} / \mathrm{m}^{2}\right)$ was calculated as follows [30]:

Algal biofilm productivity $=\left(\mathrm{M}_{\mathrm{t}}-\mathrm{M}_{0}\right) / \mathrm{A}_{\mathrm{s}}$

Where, $\mathrm{M}_{\mathrm{t}}$ and $\mathrm{M}_{0}$ is the dried mass of the tested coupons harvested at day ( $\mathrm{t}$ ) and before cultivation, respectively, while $\mathrm{A}_{\mathrm{s}}\left(\mathrm{m}^{2}\right)$ is the surface of each tested coupon.

\subsection{Experimental set-up.}

The experimental system consisted of two successive vertical reactor vessels (28x22x10 cm, LxWxH each) (Fig. 1). Eleven materials, stainless steel, silicone rubber, plexiglass, denim, sponge towel, cork, glass, geotextile, and three different patterned plexiglasses were used and were selected based on their low cost, availability, and diversity in texture. All the materials were cut in rectangular coupons $(7.4 \times 2.4 \times 0.1 \mathrm{~cm}, \mathrm{LxWxH})$.

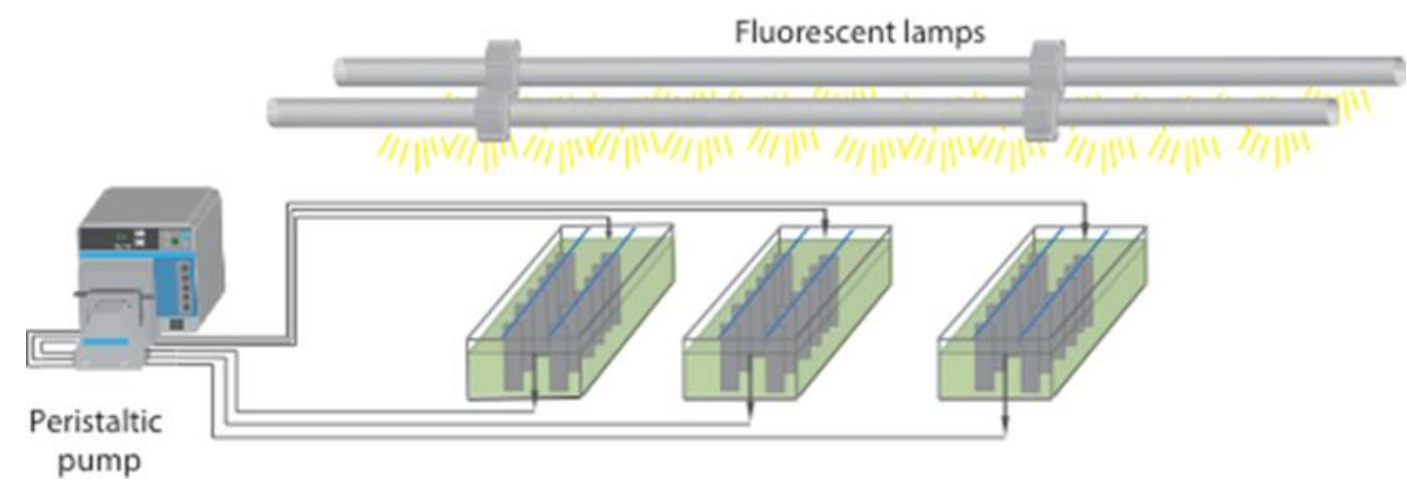

Figure 1. Experimental set-up.

The coupons were rinsed with deionized water and placed into an oven at $44^{\circ} \mathrm{C}$ for two days, and were weighted. Eleven different coupons (with a double sample for each material) were vertically hanged to a thin line into the liquid for 16 days. The algal culture was prepared from the stock precultures by appropriate dilution with $1 / 3 \mathrm{~N} \mathrm{BG}-11$ medium for the initial algal concentration to be around $240 \mathrm{mg} / \mathrm{L}$. This suspension was then transferred into the reactors. The liquid was recirculated at a flow rate of $2 \mathrm{~mL} / \mathrm{min}$ using a peristaltic pump (Masterflex L/S 7519-85, Cole Pamer Instrument, Co., USA). Two fluorescent lamps were placed above the reactors providing illumination of $100 \mu \mathrm{mol} / \mathrm{m}^{2} \mathrm{~s}$. The coupons were removed every four days from the reactors using tongs and rinsed by gently shaking on the spot. Temperature, $\mathrm{pH}$, anions concentration, optical density, turbidity, chlorophyll- a, and cell concentration were determined in the liquid each time the coupons were removed.

\subsection{Analytical methods.}

Microalgal biomass was determined by the measurement of total suspended solids (TSS) and chlorophyll-a (chl-a) according to standard methods [31]. $\mathrm{pH}$ was measured with a pH-meter (pH 300/310 waterproof Hand-held pH, Oakton Instruments, Singapore). The algal cultures' optical density was measured at $650 \mathrm{~nm}$ with a UV-Vis spectrophotometer (U-1100, Hitachi, Japan). Turbidity was measured by the nephelometric method with a laboratory turbidimeter (2100AN IS, HACH Company, USA). The free algal cell number was measured with a Neubauer hemocytometer $\left(0.1 \mathrm{~mm}, 0.0025 \mathrm{~mm}^{2}\right.$, Optic Labor, Germany) after algae staining with Lugol's solution to separate the dead from live algae. Anions concentration was determined using ion chromatography (Metrohm 850 Professional IC, Metrohm AG, 
Switzerland). A modified Lowry method was determined with total proteins, using bovine serum albumin (BSA) as standard [32]. Briefly, $5 \mathrm{mg}$ of dry microalgal biomass were placed

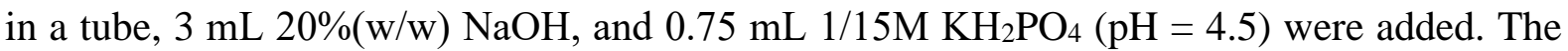
tube was vortexed and afterward heated at $100^{\circ} \mathrm{C}$ for $30 \mathrm{~min}$. The sample was cooled at room temperature, $0.125 \mathrm{ml} 20 \%(\mathrm{w} / \mathrm{w}) \mathrm{CuSO}_{4} \cdot 5 \mathrm{H}_{2} \mathrm{O}$. The mixture was centrifuged for $20 \mathrm{~min}$ at $4000 \mathrm{rpm}$. The optical density (OD) of the samples was measured at $540 \mathrm{~nm}$ in a UV-vis spectrophotometer. Total carbohydrate concentration was measured by the phenol-sulfuric method [33]. A quantity of $5 \mathrm{mg}$ dry microalgae was placed into a tube, and $5 \mathrm{~mL} \mathrm{H}_{2} \mathrm{SO}_{4}$ and $50 \mu \mathrm{L}$ phenol $(80 \% \mathrm{w} / \mathrm{v})$ were added. The sulfuric acid hydrolyzes polysaccharides into monosaccharides such as pentose and hexose that are dehydrated and rearranged into furfural hydroxymethylfurfural, respectively. These unstable products condensate with phenol, and a yellowish color appears as a result [34]. The optical density of the sample was measured after $25 \mathrm{~min}$ at $495 \mathrm{~nm}$ using a UV-vis spectrophotometer. Total carbohydrates concentration was finally determined using a glucose calibration curve. The zeta potential of suspensions of microalgae was determined using a zeta meter (Nano ZS, Malvern, UK). The zeta potential was measured in suspensions of microalgae during the operation of the opened pond biofilm system.

\subsection{Material properties.}

\subsubsection{Material characteristics.}

A total of eleven materials were tested for their capacity of supporting attached algal growth, including plexiglass, silicon rubber, stainless steel, denim, sponge towel, geotextile, cork, glass, and three different patterned plexiglasses. The materials had various characteristics such as transparency, smoothness, roughness, small and large porosity, a wide range of wettability. To determine the effect of surface patterns on biofilm development, plexiglass coupons were etched in three different ways (Fig.2). The material selection was based on low cost, durability, and the surface diversity between them.

The contact angles are commonly used to determine material's surface wettability. The higher the contact angle, the higher hydrophobicity of the material's surface. The sessile drop test was used to determine the materials' liquid contact angle, and the methodology followed is described in a previous work of our team [25]. The contact angle measurements were used to calculate the materials' surface free energy using the extended Young's equation $[35,36]$. The contact angle of the non-polar liquid tetradecane was used to quantify the surface energy component $\gamma_{\mathrm{s}}{ }^{\mathrm{LW}}$ (Lifshitz-van der Waals forces/interactions for solid) since $\gamma_{\mathrm{L}}{ }^{+}$and $\gamma_{\mathrm{L}}{ }^{-}$(acid and base interactions of the liquid) are both equal to zero for this liquid and $\gamma_{\mathrm{L}}{ }^{\mathrm{LW}}$ is known [35]. The contact angle measured with the other two liquids (water and glycerol) was used for the determination of the other two unknown surface energy parameters, $\gamma_{\mathrm{s}}{ }^{+}$and $\gamma_{\mathrm{s}}{ }^{-}$. Then, through these parameters, $\gamma_{\mathrm{s}}{ }^{\mathrm{AB}}$ (polar surface energy component) can be calculated, and finally, the total surface energy $\gamma_{\mathrm{s}}$, where is the sum of $\gamma_{\mathrm{s}}{ }^{\mathrm{AB}}$ with $\gamma_{\mathrm{s}}{ }^{\mathrm{LW}}$. An appropriate volume of B. braunii and N. vigensis was also filtered through a glass fiber filter (Whatman $47 \mathrm{~mm}$, GFA) to measure contact angle (Table 2). According to van Oss et al., the degree of hydrophobicity of materials was also determined via free energy cohesion $(\Delta \mathrm{Gcoh})$, using the water surface tension parameters.[35], shown in the following equation.

$$
\Delta \mathrm{G}_{\mathrm{coh}}=-2\left[\sqrt{\gamma_{S}^{L W}}-\sqrt{\gamma_{L}^{L W}}\right]^{2}-4\left[\sqrt{\gamma_{S}^{+} \gamma_{S}^{-}}+\sqrt{\gamma_{L}^{+} \gamma_{L}^{-}}-\sqrt{\gamma_{S}^{+} \gamma_{L}^{-}}-\sqrt{\gamma_{S}^{-} \gamma_{S}^{+}}\right]
$$




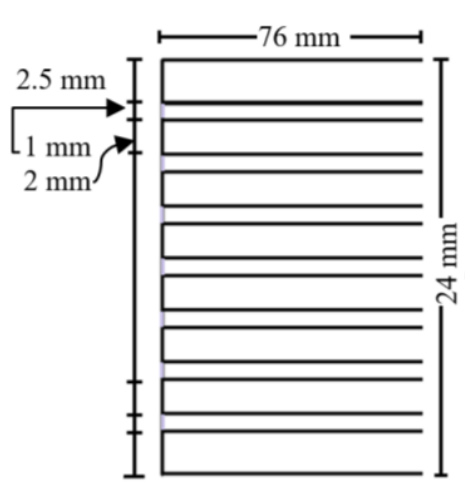

(a)

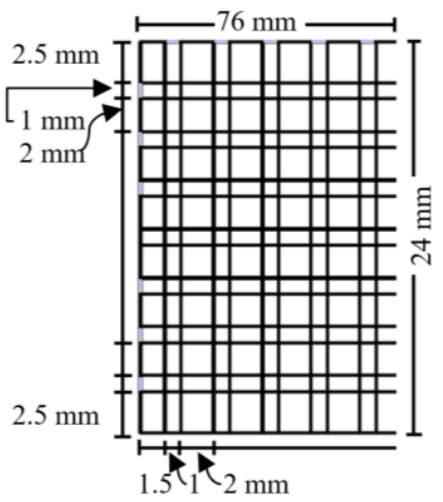

(b)

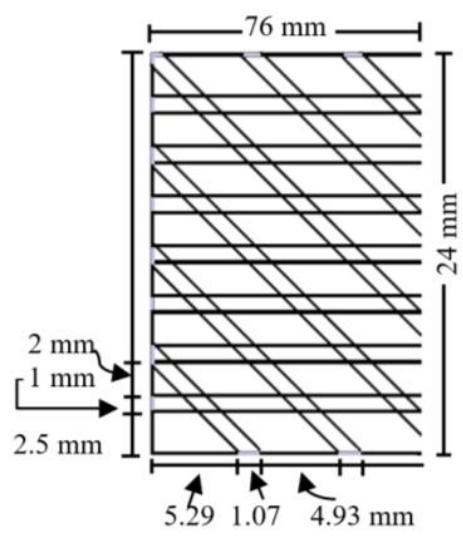

(c)

Figure 2. Plexiglass coupons were etched in three different ways: (a) Plexiglass 1: Parallel lines were drawn in the shape of groove $(1 \mathrm{~mm})$, where the space between them was $2 \mathrm{~mm}$, while the distance from each end of the coupon was $2.5 \mathrm{~mm}$. (b) Plexiglass 2: The grooves $(1 \mathrm{~mm})$ are perpendicular to each other. Both the horizontal and vertical grooves were drawn at a distance of $2 \mathrm{~mm}$ between them. The distance of horizontal grooves from each end of the coupon was $2.5 \mathrm{~mm}$, while the distance of vertical grooves from each end was $1.5 \mathrm{~mm}$. (c) Plexiglass 3: horizontal $(1 \mathrm{~mm})$ and diagonal grooves $(0.7 \mathrm{~mm})$ were engraved. The distance of horizontal and diagonal grooves from each end of the coupon was 2.5 and $4.93 \mathrm{~mm}$, respectively. The distance of horizontal grooves from each end of the coupon was $2.5 \mathrm{~mm}$, while the distance of diagonal grooves from each end was 1.5 $\mathrm{mm}$. The total number of diagonal grooves engraved on the coupon's surface was 16 .

To calculate the roughness factor $r$ on the patterned materials, the Wenzel model was applied [19]. The roughness factor $r$, is defined as the ratio of the actual surface of a rough surface to the geometrically projected area.

$$
\cos \theta^{\prime}=r \cos \theta
$$

where, $\theta^{\prime}$ is the apparent contact angle observed by a given liquid on a rough solid surface, and $\theta$ refers to the contact angle observed on the corresponding smooth surface. The roughness factor is always larger than 1.0 for a rough surface [19].

\subsubsection{Scanning electron microscopy.}

The interaction of Botryococcus braunii and Neochloris vigensis biofilm with the surface of coupons was studied by scanning electron microscopy (SEM) analysis (microscope JEOL 6300, JEOL Ltd.). Elemental analysis of the surface of the sample was also conducted. A small surface of coupon $(1 \times 1 \mathrm{~cm})$ with attached algae dehydrated in an oven and glued to SEM stubs with colloidal silver and sputter-coated with gold-palladium using a gold ion sputter coater (JEOL, JFC1100 Fine Coat). The samples were examined with SEM operating at $20 \mathrm{kV}$. For each sample, at least four fields were observed at different magnifications between 250 and 2500x.

The experiments were conducted in duplicate. All determinations were conducted in triplicate, and the data were shown as mean \pm standard deviation (SD). Data were analyzed and plotted by IGOR Pro (WaveMetrics, Inc., USA).

\section{Results and Discussion}

\subsection{Biomass growth and nutrients removal.}

The experimental data of algal cultivation of the two species (B. braunii and $N$. vigensis) are shown in Fig. 3 and 4. Fig. 3a and 4a illustrate the $\mathrm{pH}$ variation for B. braunii and 
$N$. vigensis during cultivation. $\mathrm{pH}$ values ranged from 10.3 to 11.6 for $\mathrm{B}$. braunii culturing (Fig. 3a) and from 9.2 to 11.4 for N. vigensis (Fig. 4a). All cultures presented a similar trend, with $\mathrm{pH}$ increasing when algal biomass increased. These $\mathrm{pH}$ changes are due to microalgae cells' metabolic activities and specifically the $\mathrm{CO}_{2}$ consumption from the liquid [37].

B. braunii biomass concentration in the liquid of the culture, in terms of cell and chl-a concentration, are shown in Fig. $3 b$ and 3c, respectively. The cell concentration during the operation time of the culture was increased, as was expected. B. braunii presented a higher growth rate between the $12^{\text {th }}$ and $16^{\text {th }}$ day than the days before the $12^{\text {th }}$ day of operation (Fig. $3 b$ ). This probably implies the detachment of biofilm from some materials, which has; as a result, the sudden increase of the cell number in the liquid. Many studies [38, 39] also reported the detachment of microalgae biofilm after a period of operation, which is probably due to the biofilm thickness, the hydrodynamics conditions, or the supporting material roughness of the surface. Specifically, Zammaloa et al. [39] reported that the detachment of single cells or entire parts of biofilm over time is a disadvantage in the systems of microalgae biofilm production. In order to deal with it, they developed a system of collecting the detached parts.

Chl-a concentration of B. braunii (Fig. 3c) was constantly increased during the entire period of operation. The highest chl-a concentration was on the $16^{\text {th }}$ day at $452.6 \mu \mathrm{g} / \mathrm{m}^{3}$. Chl-a concentration is dependent on nutrients (phosphorus and nitrogen) availability in the culture, and phosphorus play a more important role in algal biomass than nitrogen [40]. The variation of phosphates and nitrates concentration during biofilm production of $B$. braunii is shown in Fig. 3d. Phosphates gradually decreased through time until the $12^{\text {th }}$ day that is zero, and reaching $100 \%$ of phosphates removal by B. braunii. Similarly, nitrates concentration was decreased up to $66 \mathrm{mg} / \mathrm{L}$ and after that time remained almost steady. This indicates that consumption of phosphates and nitrates was in synergy. Orfanos and Manariotis [41] also investigated the biofilm production in opened ponds containing vertically oriented geotextiles, cotton textiles, and polyethylene sheets fed secondary effluent and reported phosphates and nitrogen removal up to 93 and $99 \%$, respectively.
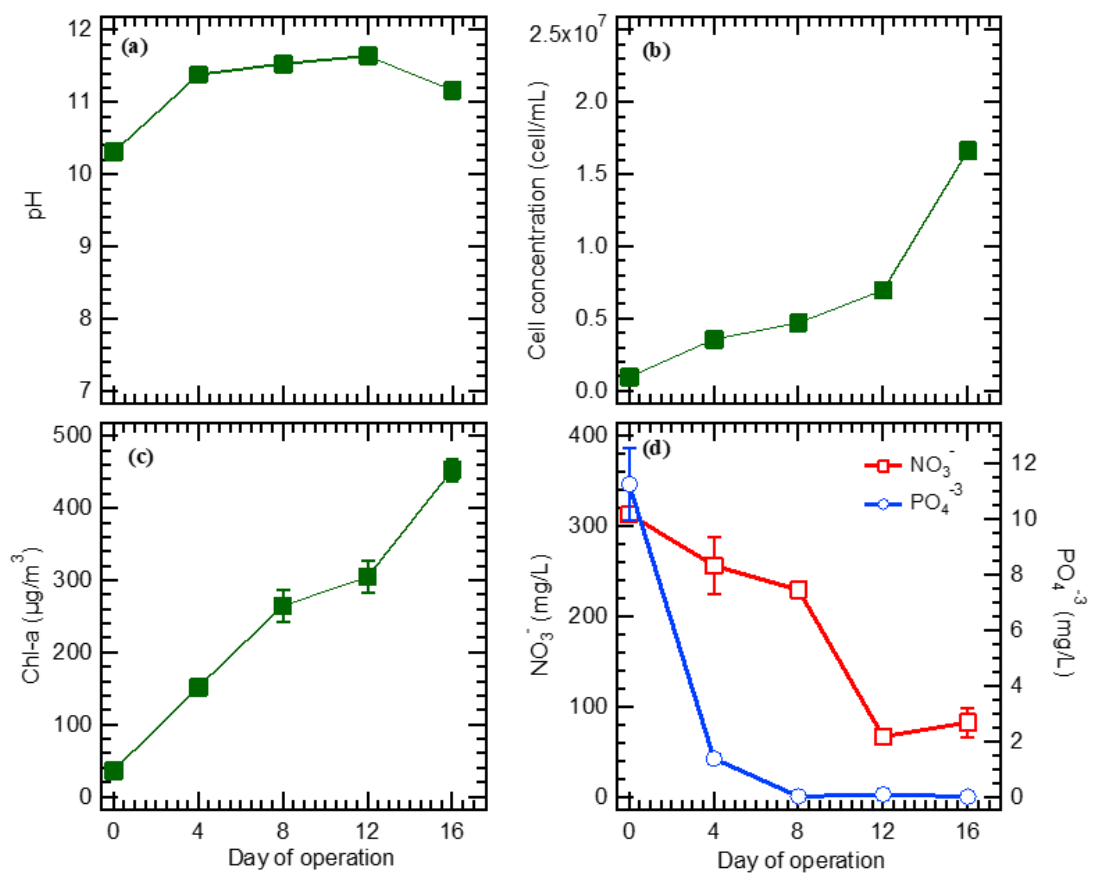

Figure 3. Cultivation of B.braunii in vertical oriented surfaces. Variation of (a) $\mathrm{pH}$; (b) cell concentration; (c) chl-a; (d) nutrients $\left(\mathrm{NO}_{3}{ }^{-}\right.$, and $\left.\mathrm{PO}_{4}{ }^{-}\right)$concentration in the liquid of reactors. The values represented mean \pm standard deviation $(\mathrm{SD})(\mathrm{n}=3)$. 
Fig. $4 \mathrm{~b}$ illustrates the growth curve on $N$. vigensis during the open pond system's operation in the liquid of the cultures. The algal growth in cell concentration presented the lag phase and the exponential phase of the algae growth. $N$. vigensis cell concentration $\left(4.00 \times 10^{6}\right.$ cells $/ \mathrm{mL})$ was lower than $B$. braunii $\left(1.66 \times 10^{7}\right.$ cells $\left./ \mathrm{mL}\right)$ on the $16^{\text {th }}$ day of operation. Although the initial concentration of cells was the same. However, the chl-a concentration (Fig. 4c) on the last day of operation was higher for $N$. vigensis than $B$. braunii. This implies the different behavior and characteristics between the algae species, which may affect biofilm production. The specific growth rate $(\mu)$ on the $16^{\text {th }}$ day of cultivation was $0.17 \mathrm{~d}^{-1}$ for B.braunii and 0.09 $\mathrm{d}^{-1}$ for N.vigensis. Fig. $4 \mathrm{~d}$ presents the nutrient removal by $N$. vigensis. As it is observed, phosphates removal reached $100 \%$ from the $4^{\text {th }}$ day of operation. On the other hand, nitrogen removal was similar to $B$. braunii. Nutrient concentration, specifically nitrogen concentration, determines the lipid content of the biomass of microalgae [42].
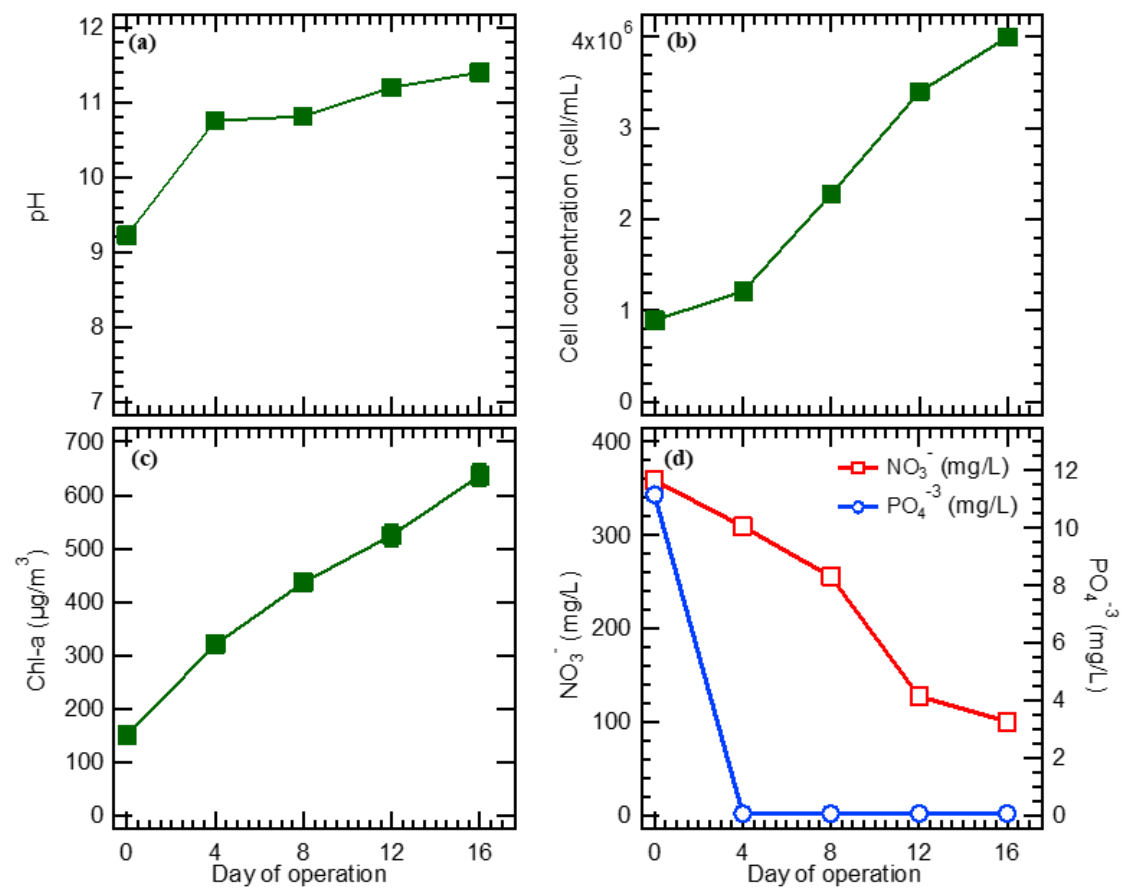

Figure 4. Cultivation of $N$. vigensis in vertically oriented surfaces. Variation of (a) $\mathrm{pH}$; (b) cell concentration; (c) chl-a; (d) nutrients $\left(\mathrm{NO}_{3}{ }^{-}\right.$, and $\left.\mathrm{PO}_{4}^{-3}\right)$ concentration in the liquid of reactors. The values represented the mean \pm standard deviation $(\mathrm{SD})(\mathrm{n}=3)$.

\subsection{Biomass characteristics.}

The lipid content of algal biomass in the liquid of cultures is presented in Fig. 5. The lipid content results for both microalgae showed that the values remained low due to the nitrogen concentration in the cultures [42]. Moreover, the differences between the cultures with the biofilm and the blank/control (only suspended algae) were not significant. Specifically, $N$.vigensis lipid content for cultures with and without biofilm were 4.7 and $4.5 \%$, respectively, and 5.7 and $6.5 \%$ for B. braunii. Other studies have reported low lipid content $(7.1 \%)$ for Scenedesmus rubescens without nitrogen starvation [25]. To increase lipid content in algal cells, stress factors should affect the cells [43]. Nitrogen starvation is the most common and the most investigated factor to obtain a high lipid algal biomass. EPS mainly consists of proteins and carbohydrates, but very often, nucleic acids, lipids, and suspended solids can also be part of EPS matrix [44]. It is like a microenvironment for the algal cells, protecting them fror dehydration and variation of $\mathrm{pH}$, temperature, and nutrient concentrations [13]. The 
biomass attached to the coupons could not be fully recovered to quantify total proteins and carbohydrates; however, the above biomaterials were measured in the liquid. The total protein content (Fig. 6a) of $N$. vigensis at the beginning of the experiment was 47\%. After 16 days, it reached $70 \%$, while the control culture was $75 \%$. High crude protein content could be suitable feed for animals and aquaculture [11].

On the other hand, total carbohydrates at the beginning were $4.4 \%$ and after 16 days was reduced to $2.7 \%$ and $1.9 \%$ for the control container (Fig. 6b). For the suspended culture of B. braunii, total proteins and carbohydrates at the beginning of the experiment were $54 \%$ and $2.6 \%$, respectively, while on $16^{\text {th }}$ day, proteins increased up to $79.9 \%$ and carbohydrates up to $3.4 \%$. Total proteins and carbohydrates content in the control liquid was $82.8 \%$ and $4.2 \%$, respectively, on $16^{\text {th }}$ day.

[ Botryococcus braunii $\square$ Neochloris vigensis

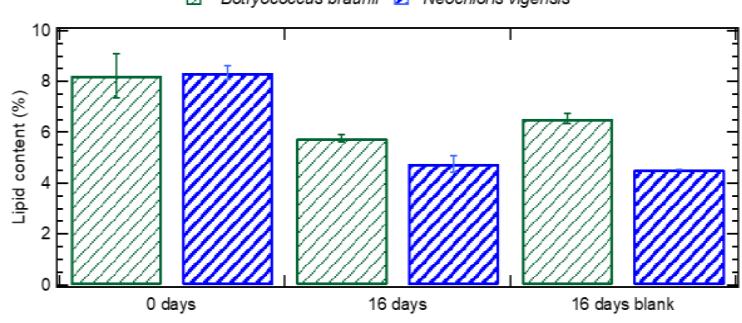

Figure 5. Lipid content of B. braunii and N.vigensis in the suspended biomass. The values represent the mean \pm standard deviation $(\mathrm{SD})(\mathrm{n}=3)$.

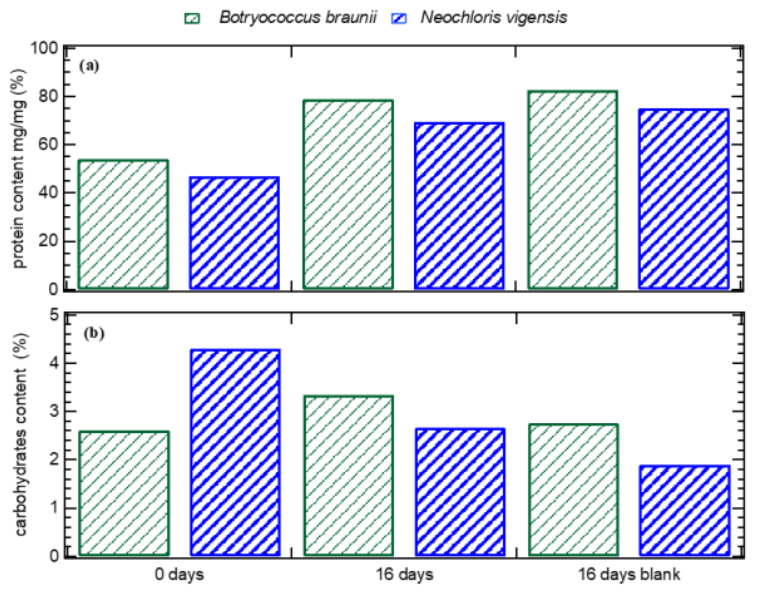

Figure 6. Cultivation of $N$. vigensis in vertically oriented surfaces. Variation of (a) proteins; (b) carbohydrates in the liquid of reactors. The values represented the mean \pm standard deviation $(\mathrm{SD})(\mathrm{n}=3)$.

\subsection{Contact angle, surface energy, and cell interactions.}

Cell-substrate interactions are the most crucial force for initial attachment. Zheng et al. [45] reported that the value of microalgae cells' zeta potential determines the suspension stability of the algae in the cultures. They also [45] supported that the zeta potential of microalgae significantly affects the microstructure of biofilm. It could be a beneficial factor for the initial attachment of the algae cells to the materials. The zeta potential of the two studied algal species during the operation for B. braunii were $-28.9 \pm 1.33 \mathrm{mV}$ and $-29.2 \pm 0.47 \mathrm{mV}$ at the beginning and the end of the experiments, respectively (Table 1). Similarly, the zeta potential values for $N$. vigensis' $s$ were $-29.9 \pm 0.09 \mathrm{mV}$ and $-28.0 \pm 0.045 \mathrm{mV}$ for day 0 and 16 , respectively. The results showed that the zeta potential between the two algae is similar and is not the main factor determining the biofilm's different development on the supporting 
materials. Many microalgae species present different zeta potential values depending on the environment and cultural conditions [45].

Table 1. Zeta potential of algal species.

\begin{tabular}{l|c|c} 
Microalgae & \multicolumn{2}{|c}{ Zeta potential $(\mathbf{m V})$} \\
\hline Botryococcus braunii & $\mathbf{0 ~ d}$ & $\mathbf{1 6 ~ d}$ \\
\hline Neochloris vigensis & $-28.9 \pm 1.33$ & $-29.2 \pm 0.47$ \\
\hline
\end{tabular}

Hydrophobicity and surface roughness are the two most important material properties. Although it is not universal, a general trend is that higher adhesion density is observed over hydrophobic surfaces. Besides hydrophobicity, surface texture favors biomass attachment, as the cells fit more properly in the grooves, especially if they have a suitable size [46]. A rough surface is a folded surface from a physicochemical point of view, where it exhibits similar interaction forces with the smooth surface [47]. By applying the theoretical equation of Wenzel, the roughness factor $r$ for Plexiglass 1 was 1.003, for Plexiglass 2 was 1.03 and for Plexiglass 3 was 1.014. Table 2 summarizes: (i) the contact angles measured by the probe liquids, (ii) the acid and base interactions (iii) the polar surface energy (iv) the surface free energy, and (v) the free energy of cohesion. The water contact angle was chosen to calculate the surface energy. As shown in Table 2, sponge towel and glass are considered hydrophilic.

Table 2. Physico-chemical surface properties of materials and microalgae.

\begin{tabular}{|c|c|c|c|c|c|c|c|c|}
\hline \multirow{2}{*}{$\begin{array}{l}\text { Material/ } \\
\text { Algae }\end{array}$} & \multicolumn{3}{|c|}{ Liquid contact angle $\theta\left({ }^{\circ}\right)$} & \multirow{2}{*}{$\begin{array}{c}\gamma_{\varsigma}^{+} \\
\left(\mathbf{m J} \cdot m^{-2}\right)\end{array}$} & \multirow{2}{*}{$\begin{array}{c}\gamma_{\varsigma^{-}} \\
\left(\mathbf{m J} \cdot \mathbf{m}^{-2}\right)\end{array}$} & \multirow{2}{*}{$\begin{array}{c}\gamma^{\mathrm{AB}} \\
\left(\mathbf{m J} \cdot \mathbf{m}^{-2}\right) \\
\end{array}$} & \multirow{2}{*}{$\begin{array}{c}\gamma_{s} \\
\left(m J \cdot m^{-2}\right)\end{array}$} & \multirow{2}{*}{$\begin{array}{c}\Delta \mathbf{G}_{\mathbf{c o h}} \\
\left(\mathbf{m J} \cdot \mathbf{m}^{-2}\right)\end{array}$} \\
\hline & Water & Glycerol & Tetradecane & & & & & \\
\hline Cork & $57.1 \pm 2.1$ & $54.6 \pm 1.9$ & $<2$ & 6.9 & 14 & 19.6 & 46.2 & -13.2 \\
\hline Silicone rubber & $66.4 \pm 2.5$ & $63.0 \pm 2.4$ & $<2$ & 3.4 & 12.1 & 12.9 & 39.5 & -20.6 \\
\hline Plexiglass & $70.9 \pm 2.8$ & $54.7 \pm 2.1$ & $39.9 \pm 1.5$ & 6 & 8.4 & 14.3 & 35.0 & -22.3 \\
\hline Stainless steel & $49.2 \pm 1.4$ & $66.5 \pm 2.8$ & $<2$ & 7.2 & 20 & 24 & 50.6 & -6 \\
\hline Denim & $<2$ & $81.3 \pm 2.9$ & $<2$ & 14.9 & 33.5 & 44.7 & 71.3 & 3.1 \\
\hline Sponge towel & $<2$ & $85.0 \pm 2.4$ & $<2$ & 14.2 & 34.5 & 44.3 & 70.9 & 3.8 \\
\hline Glass & $29.9 \pm 2.7$ & $76 \pm 1.9$ & $<2$ & 11.3 & 28.4 & 35.8 & 62.4 & 1.37 \\
\hline Geotextile & $89.9 \pm 2.2$ & $86.5 \pm 2.1$ & $<2$ & 0.07 & 7.4 & 1.5 & 28.1 & -45 \\
\hline B. braunii & $84.9 \pm 1.9$ & $65.7 \pm 1.2$ & $<2$ & 1.1 & 4.2 & 4.3 & 30.9 & -48.6 \\
\hline N. vigensis & $66 \pm 2.5$ & $77.2 \pm 2.4$ & $<2$ & 0.07 & 14.7 & 11.9 & 38.5 & -17.6 \\
\hline
\end{tabular}

${ }^{+}$Mean value \pm standard deviation $(\mathrm{SD})(\mathrm{n}=3)$.

Stainless steel and cork are presenting low wettability, while silicone rubber, plexiglass, and geotextile are hydrophobic. When surface-surface interactions are stronger than surfacewater interactions, a negative $\Delta \mathrm{G}_{\mathrm{coh}}$ indicates hydrophobicity, while a positive one means hydrophilicity [48]. Based on the free energy of cohesion, B. braunii is very hydrophobic and $N$.vigensis is less hydrophobic. As far as it concerns, the hydrophobic nature of $B$. braunii, is due to the presence of hydrophobic surface groups of the species Botryococcus over the cell walls [48]. The hydrocarbons of the cell walls contain many hydrophobic groups such as methyl and methylidene and lesser hydrophilic groups such as hydroxyl [49]. The electron donor parameter $\gamma_{\varsigma}^{-}$for the materials ranged from 7.4 to $34.5 \mathrm{~mJ} / \mathrm{m}^{2}$. For B. braunii and N.vigensis was 4.2 and $14.7 \mathrm{~mJ} / \mathrm{m}^{2}$, respectively.

On the other hand, the electron acceptor parameter $\gamma_{s}{ }^{+}$ranged from 0.07 to $14.9 \mathrm{~mJ} / \mathrm{m}^{2}$ for the materials, while for B.braunii and N.vigensis was 1.1 and $0.007 \mathrm{~mJ} / \mathrm{m}^{2}$, respectively. A higher value of $\gamma_{\zeta}{ }^{-}$is translated into a higher value of $\Delta \mathrm{G}_{\text {coh }}$ [49]. According to Zhang et al. [50], the lower difference between the surface energy of cells and substratum surfaces means the higher degree of cell attachment adhesion. However, as it turned out from Table 2, the lower difference between the surface energy of the cells of B.braunii and the materials (in 
absolute values) is in geotextile and then in plexiglass. However, plexiglass proved to be the best material for biomass production. On the other hand, with $N$. vigensis, the lower difference between the surface energy was for silicon rubber, however, the best performance material was sponge towel. The electron donor parameter $\left(\gamma_{\varsigma}^{-}\right)$of the surface free energy of hydrophilic materials is larger than that of hydrophobic, indicating larger LW interaction, shown in Table 2.

\subsection{Biomass productivity on different surfaces.}

Fig. 7a shows the attachment performance of microalgae $N$. vigensis on the surface of the different materials. On day 4, denim and cork did not show any attachment, while the best performance was presented by plexiglass, with a biomass production up to $8.1 \mathrm{~g} / \mathrm{m}^{2}$. In the second place, the plexiglass 2 and the plexiglass 1 -came with 5.9 and $5.8 \mathrm{~g} / \mathrm{m}^{2}$, respectively. Subsequently, on day 8 , plexiglass remains the best material $\left(13.3 \mathrm{~g} / \mathrm{m}^{2}\right)$, while in the second place comes the sponge towel with a productivity of $10 \mathrm{~g} / \mathrm{m}^{2}$. In the rest patterned-plexiglass coupons, the attached biomass ranged from 8.3 to $9.7 \mathrm{~g} / \mathrm{m}^{2}$.

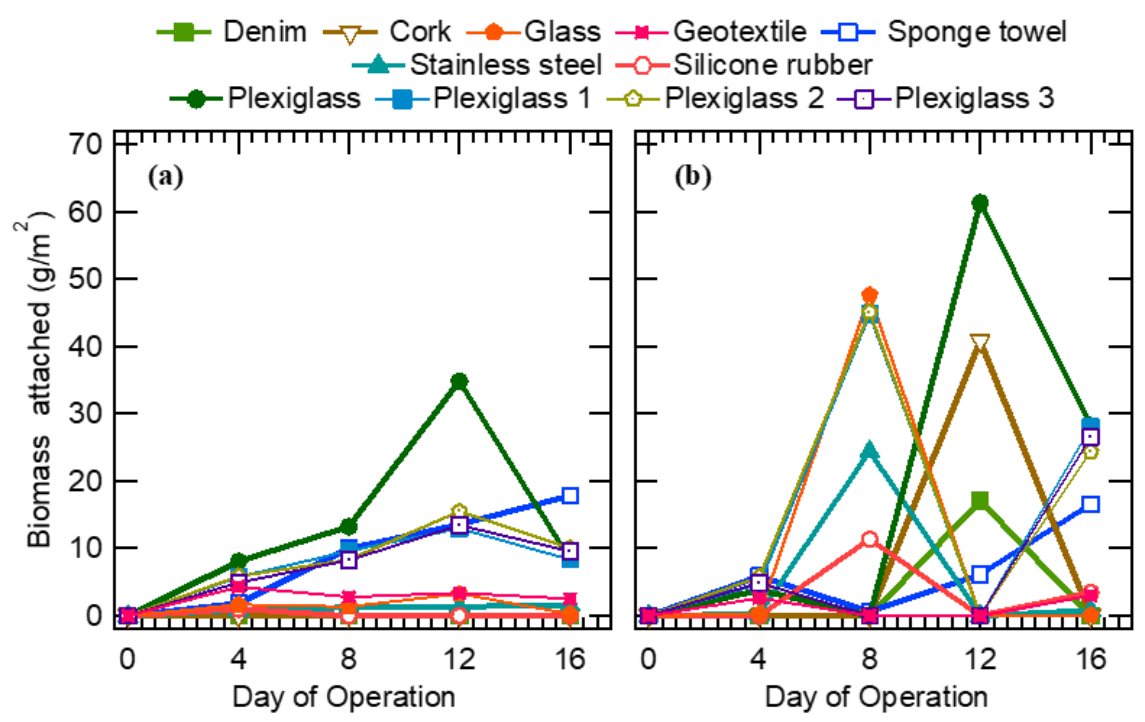

Figure 7. Biomass productivity, (a) N.vigensis (b) B.braunii.

The specific shape and rough texture did not increase the adhesion of microalgal cells onto the substrate. The next best material was geotextile $\left(2.8 \mathrm{~g} / \mathrm{m}^{2}\right)$. On day 12 , the sponge towel reached $17.8 \mathrm{~g} / \mathrm{m}^{2}$, followed by plexiglass 2 with a productivity of $10.1 \mathrm{~g} / \mathrm{m}^{2}$. In third place, plexiglass gave $8.4 \mathrm{~g} / \mathrm{m}^{2}$, while the worst performance was given by denim, cork, and silicon rubber. At the end of the operation (day 16), the sponge towel exhibited the highest productivity of $17.8 \mathrm{~g} / \mathrm{m}^{2}$ followed by the plexiglass $2\left(10.1 \mathrm{~g} / \mathrm{m}^{2}\right)$, plexiglass $3\left(9.6 \mathrm{~g} / \mathrm{m}^{2}\right)$, plexiglass $\left(8.4 \mathrm{~g} / \mathrm{m}^{2}\right)$, plexiglass $1-\left(8.3 \mathrm{~g} / \mathrm{m}^{2}\right)$, geotextile $\left(2.6 \mathrm{~g} / \mathrm{m}^{2}\right)$, stainless steel $\left(1.6 \mathrm{~g} / \mathrm{m}^{2}\right)$, glass $\left(0.3 \mathrm{~g} / \mathrm{m}^{2}\right)$, while denim, cork, and silicon rubber exhibited no productivity.

Sponge towel consists of $70 \%$ cellulose and $30 \%$ cotton and has excellent hydrophilicity. This carrier might be degraded by a wide range of microorganisms, such as bacteria and fungi [51]. The algal cell attachment might be promoted by these microorganisms, retaining the cells in the substrate layer. Additionally, algal productivity could be benefited by microbes' respiration providing $\mathrm{CO}_{2}$ and producing a high amount of extracellular polymeric substances [11]. Figure 8 represents the SEM images (in magnification 500x) of both microalgae on different materials on days 4 and 16 of cultivation. Microalgae have started to 
adhere to the material on day 4 , and by day 16 , the surfaces of all materials were covered by microalgae.

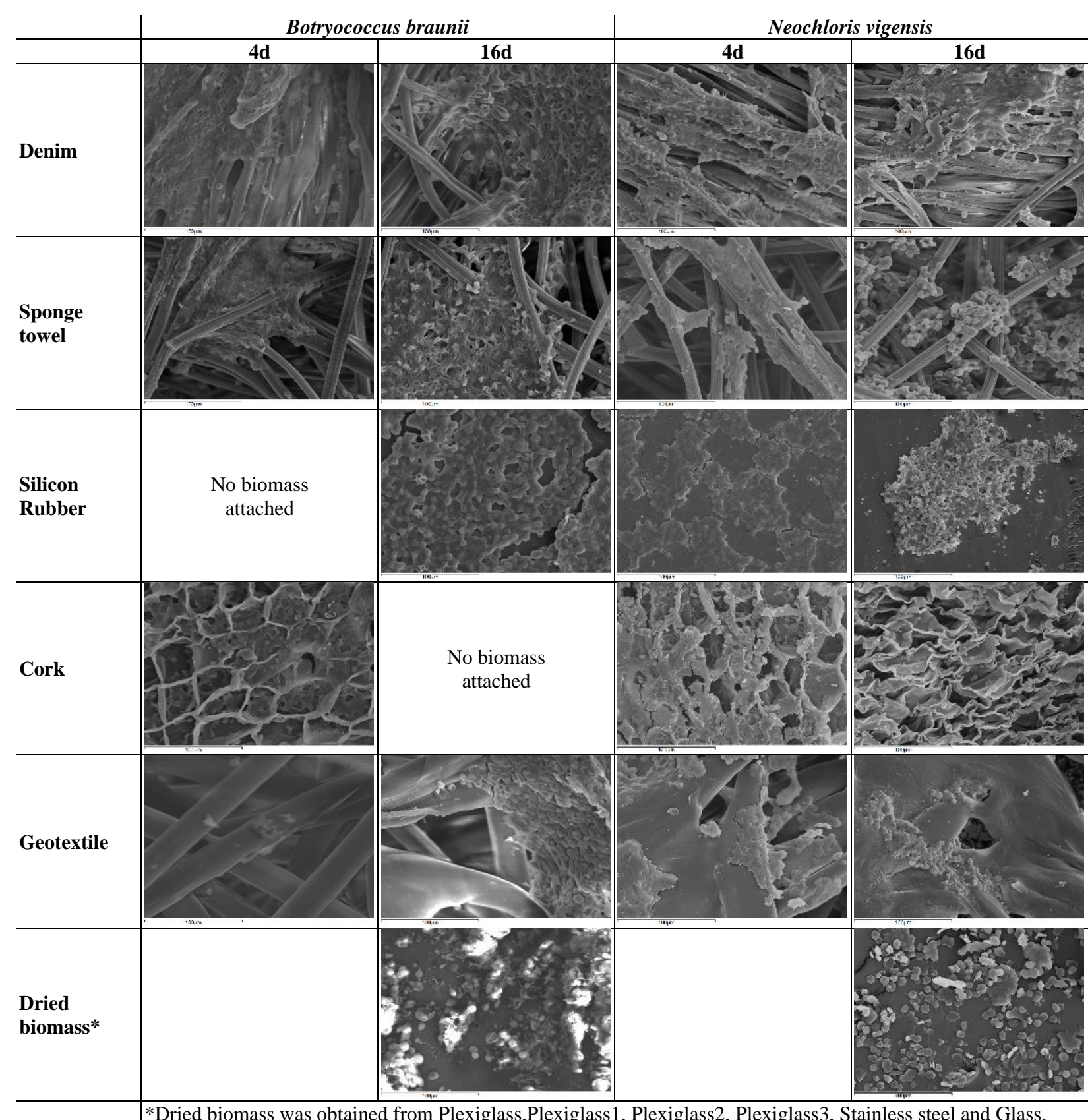

Figure 8. Scanning electron microscope images of Botryococcus braunii and Neochloris vigensis on different materials on days 4 and 16 of cultivation at a magnification of 500x.

Biofilm biomass of B. braunii is illustrated in Fig. 7a. Different materials as carriers generated significantly different biomass production. On day 4 , the sponge towel and plexiglass 2 gave the best results with 5.9 and $5.8 \mathrm{~g} / \mathrm{m}^{2}$, respectively. The plexiglass 3 and plexiglass 1 plexiglass followed with 4.9 and $4.7 \mathrm{~g} / \mathrm{m}^{2}$, respectively. Plexiglass gave $3.8 \mathrm{~g} / \mathrm{m}^{2}$, while cork, silicon rubber, and denim again, as in the case of $N$. vigensis gave the worst performance with no attachment. Surface roughness created by micropatterning aided the attachment, but it was not favorable for a long-term increase of biofilm thickness. On day $8,47.7 \mathrm{~g} / \mathrm{m}^{2}$ were attached on glass, $45.2 \mathrm{~g} / \mathrm{m}^{2}$ on plexiglass 2 , and $44.8 \mathrm{~g} / \mathrm{m}^{2}$ on plexiglass 1 . On the other hand, plexiglass and plexiglass 3 showed no production, which implies detachment of biofilm. The same behavior was observed with sponge towels, where the biomass production reduced to 0.63 
$\mathrm{g} / \mathrm{m}^{2}$. On day 12 , the plexiglass showed $61.4 \mathrm{~g} / \mathrm{m}^{2}$, and for the first time, cork showed a biomass attachment of $40.9 \mathrm{~g} / \mathrm{m}^{2}$ and denim $17.1 \mathrm{~g} / \mathrm{m}^{2}$. No biofilm appeared on the patterned plexiglass surfaces. At the end of the operation on day 16, the plexiglass showed the highest productivity of $28.3 \mathrm{~g} / \mathrm{m}^{2}$ followed by plexiglass $1\left(28 \mathrm{~g} / \mathrm{m}^{2}\right)$, plexiglass $3\left(26.6 \mathrm{~g} / \mathrm{m}^{2}\right)$, plexiglass $2(24.4$ $\left.\mathrm{g} / \mathrm{m}^{2}\right)$, sponge towel $\left(16.6 \mathrm{~g} / \mathrm{m}^{2}\right)$, silicon rubber $\left(3.43 \mathrm{~g} / \mathrm{m}^{2}\right)$, geotextile $\left(3 \mathrm{~g} / \mathrm{m}^{2}\right)$, stainless steel $\left(0.8 \mathrm{~g} / \mathrm{m}^{2}\right)$, glass $\left(0.08 \mathrm{~g} / \mathrm{m}^{2}\right)$, while denim and cork showed no productivity. Both plexiglass and cork lost biomass from day 12 to day 16 , about 33 and $40 \mathrm{~g} / \mathrm{m}^{2}$, respectively. As it is observed in SEM images, on $16^{\text {th }}$ day, the surfaces of all were fully covered (Fig.8). A larger surface area is presented in patterned substrates due to grooves, so that was the reason why patterned plexiglasses performed better. In both algal cultivations, attached biomass was visually observed on a cork, sponge towel, denim, and silicon rubber. Their surface had a greenish color. However, their actual performance is higher than recorded because denim, sponge towel, and cork break down in the water, losing part of their mass. Additionally, denim consists of cotton, which could be utilized as organic carbon by some microorganisms. As far as silicon rubber is concerned, studies have shown that it is biodegradable. The plasticizers and chemical fillers added to serve as good nutrients for microorganisms developed on polymer surfaces [52]. This is also proven by the SEM photos, where B.braunii cells on day 4 have adhered to denim, sponge towel, silicon rubber, and cork, but the biomass productivity is zero (Fig. 8).

\section{Conclusions}

The formation of two algal biofilms of B. braunii and N. vigensis on eleven different surfaces was investigated in the present work. Among the materials for B. braunii, plexiglass gave the better performance reaching up to $28.3 \mathrm{~g} / \mathrm{m}^{2}$, while for $N$. vigensis the sponge towel resulted in higher biomass productivity up to $17.8 \mathrm{~g} / \mathrm{m}^{2}$. This study's results did not confirm that hydrophobic materials are the ones with the best efficiency for all microalgae. Patterned plexiglass had the same or slightly better efficiency than the non-patterned. Some materials visually seem to be efficient; however, it can not be specified quantitatively, as there is a loss of material's weight. The strain of microalgae seems to play a crucial role in the attachment process. Especially in the case of $B$. braunii, biomass detachment was observed from the $4^{\text {th }}$ day of cultivation in a few of the materials; however, it was observed that surfaces were productive again over time.

\section{Funding}

This research is funded in the context of the project "Development of a novel attached algal photobioreactor for wastewater treatment and biomass production" (MIS 5047157) under the call for proposals "Human Resources Development, Education and Lifelong Learning 20142020" (EDULLL 103). The project is co-financed by Greece and the European Union (European Social Fund-ESF) by the Operational Programme Human Resources Development, Education and Lifelong Learning 2014-2020.

\section{Acknowledgments}

The authors would like to thank Kyriakos Bourikas from Hellenic Open University for providing the zeta meter and Katerina Govatsi from the University of Patras for recording SEM images. 


\section{Conflicts of Interest}

The authors declare no conflict of interest.

\section{References}

1. Visca, A.; Di Caprio, F.; Spinelli, R.; Altimari, P.; Cicci, A.; Iaquaniello, G.; Toro, L.; Pagnanelli, F.; Microalgae cultivation for lipids and carbohydrates production, Chem. Eng. Transact. 2017, 57, 127-132, https://doi.org/10.3303/CET1757022.

2. González-Camejo, J.; Robles, A.; Seco, A.; Ferrer, J.; Ruano, M.V. On-line monitoring of photosynthetic activity based on $\mathrm{pH}$ data to assess microalgae cultivation. J. Environ. Manage. 2020, 276, https://doi.org/10.1016/j.jenvman.2020.111343.

3. Wang, J.; Zhang, M.; Fang, Z. Recent development in efficient processing technology for edible algae: A review. Trends Food Scien. Technol. 2019, 88, 251-259, https://doi.org/10.1016/j.tifs.2019.03.032.

4. Drira, N.; Piras, A.; Rosa, A.; Porcedda, S.; Dhaouadi, H. Microalgae from domestic wastewater facility's high rate algal pond: Lipids extraction, characterization and biodiesel production. Biores. Technol. 2016, 206, 239-244, https://doi.org/10.1016/j.biortech.2016.01.082.

5. Choudhary, P.; Prajapati, K.S.; Kumar, P.; Malik, A.; Pant, K.K. Development and performance evaluation of an algal biofilm reactor for treatment of multiple wastewaters and characterization of biomass for diverse applications, Biores. Technol. 2017, 224, 276-284, https://doi.org/10.1016/j.biortech.2016.10.078.

6. Lee, S.H.; Oh, H.M.; Jo, B.H.; Lee, S.A.; Shin, S.Y.; Kim, H.S.; Lee, S.H.; Ahn, C.Y. Higher biomass productivity of microalgae in an attached growth system, using wastewater. J. Microbiol. Biotechnol. 2014, 24, 1566-1573, https://doi.org/10.4014/jmb.1406.06057.

7. Nguyen, B.T; Rittmann, B.E. Low-cost optical sensor to automatically monitor and control biomass concentration in microalgal cultivation. Algal Res. 2018, 32, 101-106, https://doi.org/10.1016/j.algal.2018.03.013.

8. Gross, M.; Henry, W.; Michael, C.; Wen, Z. Development of a rotating algal biofilm growth system for attached microalgae growth with in situ biomass harvest. Bioresour. Technol. 2013, 150, 195-201, https://doi.org/10.1016/j.biortech.2013.10.016.

9. Derakhshan, Z.; Mahvi, A.H.; Ehrampoush, M.H.; Ghaneian, M.T.; Yousefinejad, S.; Faramarzian, M.; Mazloomi, S.M.; Dehghani, M.; Fallahzadeh, H. Evaluation of kenaf fibers as moving bed biofilm carriers in algal membrane photobioreactor. Ecotoxicol. Environ. Safety 2018, 152, 1-7, https://doi.org/10.1016/j.ecoenv.2018.01.024.

10. Irving, T.E.; Allen, D.G. Species and material considerations in the formation and development of microalgal biofilms. Appl. Microbiol. Biotechnol. 2011, 92, 283-294, https://doi.org/10.1007/s00253-011-3341-0.

11. Zhang, Q.; Liu, C.; Li, Y.; Yu, Z.; Chen, Z.; Ye, T.; Wang, X.; Hu, Z.; Liu, S.; Xiao, B.; Jin, S. Cultivation of algal biofilm using different lignocellulosic materials as carriers. Biotechnol. Biofuels. 2017, 10, 1-16, https://doi.org/10.1186/s13068-017-0799-8.

12. Mantzorou, A.; Ververidis, F. Microalgal biofilms: A further step over current microalgal cultivation techniques. Sci. Total Environ. 2019, 651, 3187-3201, https://doi.org/10.1016/j.scitotenv.2018.09.355

13. Schnurr, P.J.; Allen, D.G. Factors affecting algae biofilm growth and lipid production: A review. Renew. Sustain. Energy Rev. 2015, 52, 418-429, https://doi.org/10.1016/j.rser.2015.07.090.

14. Roostaei, J.; Zhang, Y.; Gopalakrishnan, K.; Ochocki, A.J. Mixotrophic Microalgae Biofilm: A Novel Algae Cultivation Strategy for Improved Productivity and Cost-efficiency of Biofuel Feedstock Production. Sci. Rep. 2018, 8, 1-10, https://doi.org/10.1038/s41598-018-31016-1

15. Zhang, Q.; Yu, Z.; Zhu, L.; Ye, T.; Zuo, J.; Li, X.; Xiao, B.; Jin, S. Vertical-algal-biofilm enhanced raceway pond for cost-effective wastewater treatment and value-added products production. Water Res. 2018, 139, 144-157, https://doi.org/10.1016/j.watres.2018.03.076.

16. Sukačová, K.; Vícha, D.; Dušek, J. Perspectives on microalgal biofilm systems with respect to integration into wastewater treatment technologies and phosphorus scarcity. Water 2020, 12, https://doi.org/10.3390/w12082245.

17. Hoh, D.; Watson, S.; Kan, E. Algal biofilm reactors for integrated wastewater treatment and biofuel production: A review. Chem. Eng. J. 2016, 287, 466-473, https://doi.org/10.1016/j.cej.2015.11.062.

18. Garbowski, T.; Pietryka, M.; Pulikowski, K.; Richter, D. The use of a natural substrate for immobilization of microalgae cultivated in wastewater. Sci. Rep. 2020, 10, 1-9, https://doi.org/10.1038/s41598-020-646563

19. Cui, Y.; Yuan, W. Thermodynamic modeling of algal cell-solid substrate interactions. Appl. Energy. 2013, 112, 485-492, https://doi.org/10.1016/j.apenergy.2013.03.036.

20. Cui, Y.; Yuan, W.; Cao, J. Effects of surface texturing on microalgal cell attachment to solid carriers. International Journal of Agricultural and Biological Engineering 2013, 6, 644-54, https://doi.org/10.3965/j.ijabe.20130604.006.

21. Ozkan, A.; Berberoglu, H. Cell to substratum and cell to cell interactions of microalga. Colloids Surf. B Biointerfaces. 2013, 112, 302-309, https://doi.org/10.1016/j.colsurfb.2013.08.007. 
22. Palmer, J.; Flint, S.; Brooks, J. Bacterial cell attachment, the beginning of a biofilm. J. Ind. Microbiol. Biotechnol. 2007, 34, 577-588, https://doi.org/10.1007/s10295-007-0234-4.

23. Wang, J.H.; Zhuang, L.L.; Xu, X.Q.; Deantes-Espinosa, V.M.; Wang, X.X.; Hu, H.Y. Microalgal attachment and attached systems for biomass production and wastewater treatment. Renew. Sustain. Energy Rev. 2018, 92, 331-342, https://doi.org/10.1016/j.rser.2018.04.081.

24. Alexander, M.R.; Williams, P. Water contact angle is not a good predictor of biological responses to materials. Biointerphases 2017, 12, https://doi.org/10.1116/1.4989843.

25. Tsavatopoulou, V.D.; Manariotis, I.D. The effect of surface properties on the formation of Scenedesmus rubescens biofilm. Algal Res. 2020, 52, https://doi.org/10.1016/j.algal.2020.102095.

26. Desmau, M.; Carboni, A.; Le Bars, M.; Doelsch, E.; Benedetti, M.F.; Auffan, M.; Levard, C.; Gelabert, A. How Microbial Biofilms Control the Environmental Fate of Engineered Nanoparticles? Front. Environ. Scie. 2020, 8, https://doi.org/10.3389/fenvs.2020.00082.

27. Zhu, Y.; Tu, X.; Chai, X.S.; Wei, Q.; Guo, L. Biological activities and nitrogen and phosphorus removal during the anabaena flos-aquae biofilm growth using different nutrient form. Biores. Technol. 2018, 251, 712, https://doi.org/10.1016/j.biortech.2017.12.003.

28. Rosli, S.S.; Kadir, W.N.A.; Wong, C.Y; Han, F.Y.; Lim, J.W.; Lam, M.K.; Yusup, S.; Kiatkittipong, W.; Kiatkittipong, K.; Usman, A. Insight review of attached microalgae growth focusing on support material packed in photobioreactor for sustainable biodiesel production and wastewater bioremediation. Renew. Sust. Energ. Rev. 2020, 134, https://doi.org/10.1016/j.rser.2020.110306.

29. Aravantinou, A.F.; Theodorakopoulos, M.A.; Manariotis, I.D. Selection of microalgae for wastewater treatment and potential lipids production. Bioresour. Technol. 2013, 147, 130-134, https://doi.org/10.1016/j.biortech.2013.08.024.

30. Tourlouki, K.; Tsavatopoulou, V.; Alexandropoulos, D.; Manariotis, I.D.; Mazzucato, S. A novel microalgae harvesting method using laser micromachined glass fiber reinforced polymers. Photonics. 2020, 7, 1-8, https://doi.org/10.3390/photonics7020042.

31. American Public Health Association (APHA); American Water Works Association (AWWA); Water Environment Federation (WEF). Standard Methods for the Examination of Water and Wastewater. 19th ed.; American Public Health Association, American Water Works Association, Water Environment Federation: Washington, DC, USA, 1998.

32. Lowry, O.H.; Rosebrough, N.J.; Farr, A.L.; Randall R.J. Protein Measurement with the Folin Phenol Reagent. J. Biol. Chem. 1951, 193, 265-275.

33. Dubois, S.F.; Gilles, M.; Hamilton, K.A.; Rebers, P.A. Colorimetric method for determination of sugars and related substances. Microb. Cell Fact. 1956, 28, 350-356, https://doi.org/10.1021/ac60111a017.

34. Taleb, A.; Legrand, J.; Takache, H.; Taha, S.; Pruvost, J. Investigation of lipid production by nitrogenstarved Parachlorella kessleri under continuous illumination and day/night cycles for biodiesel application. J. Appl. Phycol. 2018, 30, 761-772, https://doi.org/10.1007/s10811-017-1286-0.

35. Van Oss, C.J.; Good, R.J.; Chaudhury, M.K. Additive and nonadditive surface tension components and the interpretation of contact angles. Langmuir. 1988, 4, 884-891, https://doi.org/10.1021/la00082a018.

36. Van Oss, C.J.; Chaudhury, M.K.; Good, R.J. Interfacial Lifshitz-van der Waals and polar interactions in macroscopic systems. Chem. Rev. 1988, 88, 927-941, https://doi.org/10.1021/cr00088a006.

37. Azov, Y. Effect of $\mathrm{pH}$ on inorganic carbon uptake in algal cultures. Appl. Environ. Microbiol. 1982, 43, 1300-1306. https://doi.org/10.1128/aem.43.6.1300-1306.1982.

38. Boelee, N.C.; Temmink, H.; Janssen, M.; Buisman, C.J.N.; Wijffels, R.H. Nitrogen and phosphorus removal from municipal wastewater effluent using microalgal biofilms. Water Res. 2011, 45, 5925-5933, https://doi.org/10.1016/j.watres.2011.08.044.

39. Zamalloa, C.; Boon, N.; Verstraete, W. Decentralized two-stage sewage treatment by chemical-biological flocculation combined with microalgae biofilm for nutrient immobilization in a roof installed parallel plate reactor. Biores. Technol. 2013, 130, 152-160, https://doi.org/10.1016/j.biortech.2012.11.128.

40. Liang, Z.; Soranno, P.A.; Wagner, T. The role of phosphorus and nitrogen on chlorophyll a: Evidence from hundreds of lakes. Water Res. 2020, 185, https://doi.org/10.1016/j.watres.2020.116236.

41. Orfanos, A.G.; Manariotis, I.D. Algal biofilm ponds for polishing secondary effluent and resource recovery. J. Appl. Phycol . 2019, 31, 1765-1772, https://doi.org/10.1007/s10811-018-1731-8

42. Aravantinou, A.F.; Frementiti, A.; Manariotis, I.D. Post treatment of primary and secondary effluent by Chlorococcum sp. Environ. Process. 2016, 3, 35-45, https://doi.org/10.1007/s40710-016-0153-3.

43. Feng, P.; Xu, Z.; Qin, L.; Alam, M.A.; Wang, Z.; Zhu, S. Effects of different nitrogen sources and light paths of flat plate photobioreactors on the growth and lipid accumulation of Chlorella sp. GN1 outdoors. Biores. Technol. 2020, 301, https://doi.org/10.1016/j.biortech.2020.122762.

44. Xiao, R.; Zheng, Y. Overview of microalgal extracellular polymeric substances (EPS) and their applications, Biotechnol. Adv. 2016, 34, 1225-1244, https://doi.org/10.1016/j.biotechadv.2016.08.004.

45. Zheng, Y.; Huang, Y.; Xia, A.; Qian, F.; Wei, C. A rapid inoculation method for microalgae biofilm cultivation based on microalgae-microalgae co-flocculation and zeta-potential adjustment. Biores. Technol. 2019, 278, 272-278, https://doi.org/10.1016/j.biortech.2019.01.083. 
46. Wang, J.H.; Zhuang, L.L.; Xu, X.Q.; Deantes-Espinosa, V.M.; Wang, X.X.; Hu, H.Y. Microalgal attachment and attached systems for biomass production and wastewater treatment. Renew. Sust. Energ. Rev. 2018, 92, 331-342, https://doi.org/10.1016/j.rser.2018.04.081.

47. Bos, R.; van der Mei, H.C.; Busscher, H.J. Physico-chemistry of initial microbial adhesive interactions - its mechanisms and methods for study. FEMS Microbiol. Rev. 1999, 23, 179-230.

48. Ozkan, A.; Berberoglu, H. Physico-chemical Surface Properties of Microalgae. Colloids Surf B Biointerfaces 2013, 112, 287-293, https://doi.org/10.1016/j.colsurfb.2013.08.001.

49. Eroglu, E.; Melis, A. Extracellular terpenoid hydrocarbon extraction and quantitation from the green microalgae Botryococcus braunii var. Showa. Bioresour. Technol. 2010, 101, 2359-2366, https://doi.org/10.1016/j.biortech.2009.11.043

50. Zhang, X.; Zhang, Q.; Yan, T.; Jiang, Z.; Zhang, X.; Zuo, Y.Y. Quantitatively predicting bacterial adhesion using surface free energy determined with a spectrophotometric method. Environ Sci Technol. 2015, 49, 6164-71, https://doi.org/10.1021/es5050425.

51. Lynd, L.R.; Weimer, P.J.; Van Zyl, W.H.; Pretorius, I.S. Microbial Cellulose Utilization: Fundamentals and Biotechnology. Microbiol. Mol. Biol. Rev. 2002, 66, 506-577, https://doi.org/10.1128/MMBR.66.3.506577.2002.

52. Gu, J.G. Gu, J.D. Methods currently used in testing microbiological degradation and deterioration of a wide range of polymeric materials with various degree of degradability: A review. J. Polym. Environ. 2005, 13, 65-74, https://doi.org/10.1007/s10924-004-1230-7. 